\title{
Complement C1 Esterase Inhibitor Measurement
}

National Cancer Institute

\section{Source}

National Cancer Institute. Complement C1 Esterase Inhibitor Measurement. NCI

Thesaurus. Code C147313.

The determination of the amount of complement C1 esterase inhibitor present in a sample. 